Bayero Journal of Pure and Applied Sciences, 10(1):184 - 187

ISSN 2006 - 6996

\title{
ANTIBACTERIAL ACTIVITY OF FRUIT AND BARK EXTRACTS OF Tamarindus indica Against Escherichia coli AND Staphylococcus aureus
}

\author{
Aliyu, A.M., Musa, F.M. and Abeku, R. \\ Department of Applied Science C.S.T. Kaduna Polytechnic Kaduna, Nigeria. \\ Correspondence author:aisha2zra@yahoo.com +2348035890640
}

\begin{abstract}
The preliminary antibacterial activity of fruit and bark extracts of Tamarindus indica was evaluated against Escherichia coli and Staphylococcus aureus using agar well diffusion method. The bioactive components of the dried powdered plant parts were extracted using aqueous, ethanol and acetone solvents. The ethanol fruit extract of $T$. indica was found to be effective at different concentrations of $6.25 \mathrm{mg} / \mathrm{ml}-100 \mathrm{mg} / \mathrm{ml}$, with mean zone of inhibition ranging between $6.0 \pm 2.5 \mathrm{~mm}-20.0 \pm 4.5 \mathrm{~mm}$ for $S$. aureus and $5.0 \pm 2.2 \mathrm{~mm}-19.0 \pm 4.5 \mathrm{~mm}$ for $E$. coli. Aqueous extract at $6.25 \mathrm{mg} / \mathrm{ml}-100 \mathrm{mg} / \mathrm{ml}$ concentrations, had mean zone of inhibition of $10.0 \pm 3.2 \mathrm{~mm}-23.0 \pm 4.8 \mathrm{~mm}$ for $S$. aureus and $9.0 \pm 3.0-20.0 \pm 4.5 \mathrm{~mm}$ for $E$. coli. Acetone extract at $6.25 \mathrm{mg} / \mathrm{ml}-100 \mathrm{mg} / \mathrm{ml}$ concentrations, had mean zone of inhibition of $3.0 \pm 1.7-18.0 \pm 4.5 \mathrm{~mm}$ for S. aureus and 3.0 $\pm 1.7-9.0 \pm 3.0 \mathrm{~mm}$ for $E$. coli. For the bark extract of $T$. indica, ethanol extract at $6,25 \mathrm{mg} / \mathrm{ml}-100 \mathrm{mg} / \mathrm{ml}$ concentrations, had a mean zone of inhibition ranging between $4.0 \pm 2.0-16 \pm 4.0 \mathrm{~mm}$ for $S$. aureus and 1.0 1 1.0-9.0 $\pm 3.0 \mathrm{~mm}$ for $E$. coli. Aqueous extract at $6.25 \mathrm{mg} / \mathrm{ml}-100 \mathrm{mg} / \mathrm{ml}$ had mean zone of inhibition of $5.0 \pm 2.2-20 \pm 4.5 \mathrm{~mm}$ for S. aureus and $2.0 \pm 1.4-6.0 \pm 2.4 \mathrm{~mm}$ for $E$. coli. For the fruit, aqueous extract had MIC value of $12.5 \mathrm{mg} / \mathrm{ml}$ and $M B C$ value of $25 \mathrm{mg} / \mathrm{ml}$ for both $E$. coli and S.aureus, ethanol extract had MIC value of $6.25 \mathrm{mg} / \mathrm{ml}$ and $M B C$ value of $12.5 \mathrm{mg} / \mathrm{ml}$ for both $E$. coli and $S$. aureus, while acetone extract had MIC value of $6.25 \mathrm{mg} / \mathrm{ml}$ and $M B C$ value of $12.5 \mathrm{mg} / \mathrm{ml}$ for $E$. coli and $M I C$ value of $12.5 \mathrm{mg} / \mathrm{ml}$ and $M B C$ value of $25 \mathrm{mg} / \mathrm{ml}$ for $\mathrm{S}$. aureus. For the bark, aqueous extract had MIC value of $12.5 \mathrm{mg} / \mathrm{ml}$ and $M B C$ value of $25 \mathrm{mg} / \mathrm{ml}$ for both E.coli and S. aureus. Ethanol extract had $M I C$ value of $6.25 \mathrm{mg} / \mathrm{ml}$ and $M B C$ value of $12.5 \mathrm{mg} / \mathrm{ml}$ for both $E$. coli and $S$. aureus. Acetone extract had MIC value of $12.5 \mathrm{mg} / \mathrm{ml}$ and $M B C$ value of $25 \mathrm{mg} / \mathrm{ml}$ for both $E$. coli and $S$. aureus. The results support the use of the plant parts as therapeutic agents against diseases caused by $E$. coli and S. aureus.

Key words: Antibacterial Activity, Tamarindus indica, Escherichia coli, Staphylococcus aurues
\end{abstract}

\section{INTRODUCTION}

A medicinal plant is any plant in which one or more of its organs contains substances that can be used for therapeutic purpose or which are precursors for the synthesis of useful drugs (WHO, 2007). Medicinal plants are of great importance to the health of individuals and communities. The medicinal value of these plants lies in some chemical substances that produce a definite physiological action on the human body, the most important of these bioactive constituent of plants are alkaloids, tannins, flavonoids and phenolic compounds. Many of these indigenous medicinal plants are used as spices and food (Baris et al., 2006). Since the beginning of civilization, man has exploited plant for food, clothing, fuel, timber and phytomedicine (Bibitha et al. 2002). Traditional medicines produced from traditional plants were formerly used as an alternative to orthodox medicine, it is estimated that $80 \%$ of the world population is dependent on traditional medicine for various illness and $80 \%$ of such treatment are plant based. The emergence of multi-drug resistant pathogens, the appearance of strains with reduced susceptibility as well as side effects of some antibiotics, threatened the clinical efficacy of many existing antibiotics (Yusha'u and Bello, 2016).

Tamaridus indica commonly known as the tamarind and locally known as tsamiya is a medium sized tree belonging to the family fabiceae and subfamily caesalpinaceae, which is the third largest family of flowering plants with a total of 727 genera and 19,327 specie. The tamarind is a tropical evergreen tree native to fertile areas throughout Africa and Southern Asia. The tree grows well in full sun and clay, loamy, sandy and acidic soil types and is drought resistance (Doughari, 2006).

The aim of this paper is to determine the antibacterial activity of fruit and bark extract of Tamarindus indica against Staphylococcus aureus and Escherichia coli using different solvents (aqueous, ethanol and acetone). 


\section{MATERIALS AND METHODS \\ Sample Collection}

The fruit and bark of $T$. indica were obtained from Unguwan Boro of Chikun local Government Area of Kaduna State Nigeria. The plant was identified with voucher number 602 at the herbarium of Biological Science Department Faculty of Life Science Ahmadu Bello University Zaria, kaduna State, Nigeria.

Bacterial Isolates

The test organisms were obtained from the Microbiology laboratory of the Barau Dikko Teaching Hospital Kaduna.

Biochemical Characterization of the Isolates After 24hours of incubation at $37^{\circ} \mathrm{C}$, the colonial morphology of the isolates was observed and then subjected to Gram staining reaction and biochemical characterization (Cheesbrough, 2006).

\section{Extraction of Bioactive Components}

Plants extraction was done using maceration method using three different solvents (water, ethanol and acetone). Fifty $(50 \mathrm{~g})$ of the grounded bark was weighed and soaked in $500 \mathrm{ml}$ of each solvent used. The same procedure was carried out on the fruit samples. The mixture was allowed to stand for three days with vigorous shaking. The mixtures were then filtered separately using Whatman's no 1 filter paper. The filtrates were further evaporated to dryness under a steady air current. All the dried extracts were stored in sterile specimen bottles at room temperature until required for further use (Green, 2004).

Preparation of standard Inocula

A standard inoculum was prepared using previously overnight broth culture of each of the test organism by diluting with sterile saline solution to march Mcfarland standard. The standardized inoculum was used for the antibacterial activity testing (Akinpelu and Onokoya,2006).
Antibacterial Activity Testing

Agar well diffusion method was used to test the antibacterial activity of the fruit and bark extracts. The standardized inoculm was pipetted and poured on a sterile petri dish aseptically and about $20 \mathrm{ml}$ of sterilized Muller Hinton agar was poured, the mixture was swired and allowed to solidify. Equidistant wells of $6 \mathrm{~mm}$ in diameter and $4 \mathrm{~mm}$ in depth were pounched on the solidified agar plates using sterile cork borer. Varied concentrations of $100 \mathrm{mg} / \mathrm{ml}, 50 \mathrm{mg} / \mathrm{ml}, 25 \mathrm{mg} / \mathrm{ml}, 12.5 \mathrm{mg} / \mathrm{ml}$ and $6.25 \mathrm{mg} / \mathrm{ml}$ of the extract were prepared. The wells were filled each with the different concentrations of the extracts and were allowed to stand for 2hours at room temperature to prediffuse into the agar and was then incubated at $37^{\circ} \mathrm{C}$ for 24 hours. This was done in duplicates. Sensitivity of the organisms to the extract was recorded (Babitha et al., 2002).

Determination of Minimum Inhibitory Concentration (MIC)

The minimum inhibitory concentration was determined by the broth dilution methods. Each concentration of the extracts was dispensed into sterile nutrient broth. Each test tube was inoculated with $1.0 \mathrm{ml}$ of the test organisms. This was done in duplicate and was incubated at $37^{\circ} \mathrm{C}$ for 24 hours. The tubes were examined for bacterial growth by observing turbidity. The lowest concentration where there was no turbidity was observed and recorded for MIC.

Determination of Minimum Bactericidal Concentration (MBC)

For each set of test tubes in MIC determined, a loopful of broth was collected from those tubes that shows no turbidity and was inoculated on sterile nutrient agar plates by streaking and was incubated at $37^{\circ} \mathrm{C}$ for 24 hours, this was done in duplicate. The concentration, at which no visible growth was observed, was recorded as MBC. 
RESULTS

Table 1: Mean zone of inhibition of fruit and bark extracts of $T$. indica against $E$. coli and S.aureus

\begin{tabular}{lcccccc}
\hline & & & \multicolumn{5}{c}{ Concentration (mg/ml) } \\
Isolates & 100 & 50 & 25 & 12.5 & 6.25 & control cipro (25) \\
\hline $\begin{array}{l}\text { Fruit extract } \\
\text { Ethanol }\end{array}$ & & & & & & \\
S. aureus & $20 \pm 4.5$ & $16 \pm 4.0$ & $12 \pm 3.5$ & $9 \pm 3.0$ & $6 \pm 2.5$ & $32 \pm 0.5$ \\
E. coli & $19 \pm 4.3$ & $13 \pm 3.6$ & $9 \pm 3.0$ & $13 \pm 1.7$ & $5 \pm 2.2$ & $30 \pm 0.8$ \\
Aqueous & & & & & & \\
S. aureus & $23 \pm 4.8$ & $20 \pm 4.5$ & $18 \pm 4.2$ & $16 \pm 4.0$ & $10 \pm 3.2$ & $34 \pm 0.8$ \\
E. coli & $20 \pm 4.5$ & $19 \pm 4.3$ & $16 \pm 4.0$ & $13 \pm 3.6$ & $9 \pm 3.0$ & $32 \pm 0.5$ \\
Acetone & & & & & & \\
S. aureus & $18 \pm 4.2$ & $15 \pm 3.9$ & $12 \pm 3.5$ & $8 \pm 2.8$ & $3 \pm 1.7$ & $32 \pm 0.8$ \\
E. coli & $9 \pm 3.0$ & $7 \pm 2.6$ & $5 \pm 2.3$ & $4 \pm 2.0$ & $3 \pm 1.7$ & $30 \pm 0.8$ \\
Bark extract & & & & & & \\
Ethanol & & & & & & \\
S. aureus & $16 \pm 4.0$ & $11 \pm 3.3$ & $9 \pm 3.0$ & $6 \pm 2.5$ & $4 \pm 2.0$ & $28 \pm 0.8$ \\
E. coli & $9 \pm 3.0$ & $7 \pm 2.6$ & $5 \pm 2.2$ & $3 \pm 1.7$ & $1 \pm 1.0$ & $24 \pm 0.5$ \\
Aqueous & & & & & & \\
S. aureus & $20 \pm 4.5$ & $14 \pm 3.7$ & $10 \pm 3.2$ & $8 \pm 2.8$ & $5 \pm 2.2$ & $31 \pm 0.5$ \\
E. coli & $16 \pm 4.0$ & $11 \pm 3.3$ & $9 \pm 3.0$ & $5 \pm 2.2$ & $2 \pm 1.4$ & $30 \pm 0.8$ \\
Acetone & & & & & & \\
S. aureus & $9 \pm 3.0$ & $6 \pm 2.5$ & $3 \pm 1.7$ & $2 \pm 1.4$ & $2 \pm 1.4$ & $28 \pm 0.8$ \\
E. coli & $6 \pm 2.4$ & $5 \pm 2.2$ & $3 \pm 1.7$ & $3 \pm 1.7$ & $2 \pm 1.4$ & $24 \pm 0.8$ \\
\hline
\end{tabular}

Table 2: Minimum Inhibitory and Minimum Bactericidal Concentrations $(\mathrm{mg} / \mathrm{ml})$ of both fruit and bark extracts of Tamarindus indica

\begin{tabular}{lccc}
\hline Isolates & $\begin{array}{c}\text { Extracts } \\
\text { Ethanol }\end{array}$ & Aqueous & Acetone \\
\hline Fruit Extract & & & \\
S. aureus & $6.25(12.5)$ & $12.5(25)$ & $12.5(25)$ \\
E. coli & $6.25(12.5)$ & $12.5(25)$ & $6.25(25)$ \\
Bark Extract & & $12.5(25)$ & $12.5(25)$ \\
S. aureus & $6.25(12.5)$ & $12.5(25)$ & $12.5(25)$ \\
E. coli & $6.25(12.5)$ & &
\end{tabular}

Key: ()$=$ MBC values

DISCUSSION

The result of the antibacterial activities of the extracts of $T$. indica against $E$. coli and $S$. aureus showed that the fruit extract is more effective than the bark extracts. This could be due to the acid content of the fruit and the presence of phytoconstituents. This shows that $T$. indica can serve as a phytomedicine or as a basis for the development of new drug effective against the types of bacteria used. The result also showed variation in the degree of antibacterial activities of the extracts on the test bacteria. The variations are presumed to be due to different compositions of active components present in the plant. The fruit and bark extracts of $T$. indica showed more antibacterial activity against $S$. aureus compared to $E$. coli, which is in agreement with the findings of Marjorie (2012), who reported that Gram negative bacteria are more resistant than Gram positive bacteria due to cell wall nature of the organisms. Gram negative bacteria have high level of lipid materials which help to prevent injurious chemicals from reaching the site of action of the cell (Okwu and Josiah, 2006). This study also showed that the aqueous fruit and bark extracts had higher inhibitory activity on the test organisms when compared to ethanol and acetone. This could be due to the polarity of the solvents used and solubilities of the compounds present in the plant extracts. Ethanol is less polar than water and more polar than acetone.

The $M B C$ results from the extracts of the different plant parts are found to be higher than the MIC value. That is, the extracts are bacteriostatics at lower concentrations and bactericidal at higher concentrations. Although this may be attributed to the fact that the extracts are in their crude form and may contain very small amount of the bioactive compounds. This agrees with Akinyemi et al. (2006) which stated that $M B C$ values obtained for the crude extracts against the pathogens are higher than MIC values. 
CONCLUSION

Tamaridus indica fruit and bark extracts have potent bioactive ingredients with antibacterial activity, showing that the fruit and bark extracts of $T$. indica are bactericidal and have

\section{REFERENCES}

Akinpelu, D.A. and Onokoya, T.M. (2006). Antimicrobial Activities of Medicinal Plants used in Folklore Remedies in South-Western. Africa. Journal of Biotechnology, 5:1078-1081.

Akinyemi, K.O., Oluwa, O.K. and Omomigbehin, E.O. (2006). Antimicrobial Activity of Crude Extracts of Three Medicinal Plants used in South-West Nigerian Folk Medicine on Some Food Bacterial Pathogen. African Journal of Traditional, Complementary and Alternative Medicine, 3(4):13-22.

Babitha, B., Jisha, V.K., Salitha, C.V., Mohan, S. and Valsa, A.K. (2002). Antibacterial Activity of Different Plant Extracts. Short Communication. Indian Journal of Microbiology, 42:361-363.

Baris, O., Gulluce, M., Sahin, F., Ozer, H., Killie, H., Ozkan, H., Sokmen, M. and Ozbek, T. (2006). Biological Activities of the Essential oil and Methanol Extracts of Achillea biebersteinii afan (Asteraceae).Turkish Journal of Biology, 30:65-73. broad spectrum of activity against the test bacteria. The overall result support the traditional use of the plant parts against diseases caused by E. coli and S. aureus.

Cheesbrough, M. (2006). District Laboratory Practice in Tropical Countries, Volume2 second Ed. Cambridge University Press, England, Pp62-70.

Doughari, J.H. (2006). Antimicrobial activity of Tamarindus indica linn. Tropical Journal of Pharmaceutical Research, 5(12):597-603.

Green, R.J. (2004). Antioxidant Activity of Peanut Plant Tissue. Phytopathology, 52:876-880.

Majorie, M.C. (2012). Plant Products as Antibacterial Agents. Clinical Microbiology Reviews, 12(4):564-582.

Okwu, D.E. and Josiah, C. (2006). Evaluation of the Chemical Composition of two Nigerian Medicinal Plants.African Journal of Biotechnology, 5(4):357-361.

World Health Organization (2007). Quality Control Methods for Medicinal Plant Material, Geneva, 28-33.

Yusha'u, M. and Bello, M. (2016).Antibacterial Profile of Turmeric Powder against some Clinical Bacterial Isolates. Nigerian Journal of Scientific Research, 15(2):321-328. 